\title{
Article \\ Comparison of Initial pH Adjustment Prior to Thermophilic Anaerobic Digestion of Lime-Treated Corn Stover via Liquid Digestate or $\mathrm{CO}_{2}$
}

\author{
Lei Xiao, Man Yang, Di Hu, Yuxia Mei, Shumiao Zhao and Yunxiang Liang *D \\ State Key Laboratory of Agricultural Microbiology, College of Life Science and Technology, \\ Huazhong Agricultural University, Wuhan 430070, China; xiaol@webmail.hzau.edu.cn (L.X.); \\ yman@webmail.hzau.edu.cn (M.Y.); hdi@webmail.hzau.edu.cn (D.H.); mei@mail.hzau.edu.cn (Y.M.); \\ shumiaozhao@mail.hzau.edu.cn (S.Z.) \\ * Correspondence: liangyunxiang@mail.hzau.edu.cn
}

Citation: Xiao, L.; Yang, M.; Hu, D.; Mei, Y.; Zhao, S.; Liang, Y.

Comparison of Initial pH Adjustment Prior to Thermophilic Anaerobic Digestion of Lime-Treated Corn Stover via Liquid Digestate or $\mathrm{CO}_{2}$. Appl. Sci. 2021, 11, 10884. https:// doi.org/10.3390/app112210884

Academic Editor: Ramaraj Boopathy

Received: 3 October 2021

Accepted: 12 November 2021

Published: 18 November 2021

Publisher's Note: MDPI stays neutral with regard to jurisdictional claims in published maps and institutional affiliations.

Copyright: (c) 2021 by the authors. Licensee MDPI, Basel, Switzerland. This article is an open access article distributed under the terms and conditions of the Creative Commons Attribution (CC BY) license (https:/ / creativecommons.org/licenses/by/ $4.0 /)$.

\begin{abstract}
Neutralization with liquid digestate and $\mathrm{CO}_{2}$ was compared herein to adjust the $\mathrm{pH}$ of lime-treated corn stover. The effects on the thermophilic $\left(55^{\circ} \mathrm{C}\right)$ anaerobic digestion were also analyzed. Liquid digestate neutralization (LDN) caused a decrease in $\mathrm{pH}$ from 10.5 to $7.5 \mathrm{in} 60 \mathrm{~h}$ and accumulation of acetic/isobutyric acids. The $\mathrm{CO}_{2}$ neutralization $(\mathrm{CN})$ under solid-state conditions reduced the $\mathrm{pH}$ from 10.5 to 8.5 in $30 \mathrm{~min}$, which is faster than that of LDN and did not affect the subsequent anaerobic digestion. Biomethane production rate indicates that LDN contributed to the performance of anaerobic digestion, but this was not sufficient to compensate for the loss of total biomethane yield, resulting in a negative net profit (i.e., revenue from increased energy production minus reagent cost). For $\mathrm{CN}$ under solid-state conditions, the biomethane production was highest in both liquid- and solid-state anaerobic digestion, and also obtained a net profit of 98.74-100.89 RMB/tonne dry biomass. Therefore, the solid-state condition $\mathrm{CN}$ is a more efficient and economic method for adjusting initial $\mathrm{pH}$ of lime-treated corn stover.
\end{abstract}

Keywords: thermophilic anaerobic digestion; liquid digestate; carbon dioxide; lime pretreatment; corn stover

\section{Introduction}

Anaerobic digestion (AD) is an environment-friendly and sustainable technology for the treatment of agricultural residues for recovering energy in the form of biogas and organic fertilizer raw materials in the form of digestates [1,2]. AD can be categorized according to the total solids (TS) content as liquid AD (L-AD) and solid-state AD (SS-AD) [3], and it can also be grouped into mesophilic AD $\left(30-40{ }^{\circ} \mathrm{C}\right)$ and thermophilic AD $\left(50-60{ }^{\circ} \mathrm{C}\right)$, according to the operating temperature $[4,5]$. As less moisture increases equipment efficiency and reduces heating demand [6], while higher fermentation temperatures accelerate biogas production and reduce retention time [4], a growing corpus of studies has been focused on thermophilic SS-AD [7-9].

As a representative member of the agricultural residues, corn stover (CS) primarily comprises three types of polymers: cellulose, hemicellulose, and lignin. However, a rigid three-dimensional matrix formed by cross-linking the three components constrains the efficient biological deconstruction [6]. Thus, pretreatment is generally required prior to AD for enhancing the enzymatic accessibility and subsequent biodegradability of CS. Various pretreatment strategies have been previously used for lignocellulosic biomass, including biological, physical, chemical, physicochemical, and combined methods [10]. Among the existing pretreatment technologies, alkali pretreatment is considered one of the most promising options, considering its high efficiency in delignification and high final total sugar yields [11]. Calcium hydroxide/calcium oxide has been extensively studied as a potential reagent based on the cost-efficiency [12-14]. $\mathrm{Ca}(\mathrm{OH})_{2}$ single-batch pretreatment 
and $\mathrm{NaOH}$ consecutive-batch pretreatment with leachate reuse have been compared for giant reed. The net benefit (revenue from increased energy production minus chemical cost) of $\mathrm{Ca}(\mathrm{OH})_{2}$ pretreatment was positive at \$1.1-5.8/ton dry biomass, whereas that of the $\mathrm{NaOH}$ was negative [15]. As the solubility of $\mathrm{Ca}(\mathrm{OH})_{2}$ in water is considerably lower than that of $\mathrm{NaOH}$ or $\mathrm{KOH}$, some of the unreacted solids remaining on the surface of the biomass were wasted. Therefore, a recirculating system for the saturated lime solution was introduced by researchers [16] to further reduce the chemical costs.

However, the final $\mathrm{pH}$ after the alkali pretreatment process is typically $>10.0$, while the acceptable $\mathrm{pH}$ for $\mathrm{AD}$ is typically in the range of 6.5-8.5. Therefore, lowering the $\mathrm{pH}$ to the range where $\mathrm{AD}$ can be successfully initiated is the required step, including washing with deionized water, adding organic or mineral acids [17], or using gaseous carbon dioxide or biogas to neutralize alkali $[18,19]$. These methods suffer from considerable limitations for practical applications, despite the fact that they are easily applicable in the laboratory conditions. The large volumes of wastewater generated during the washing process or bubbling gases and the extra chemical costs caused by adding acids should be considered by the industry.

Liquid digestate (LD) from AD systems is rich in microbes for bioconversion. Previous studies have reported that LD could be utilized as a microbial agent for the bio-pretreatment of lignocellulosic biomass [20-23]. Notably, acidogens from these microbes are also potential candidates for reducing the $\mathrm{pH}$. Additionally, enzymes from microorganisms can attack inert lignocellulose and convert it into volatile fatty acids (VFAs) that are easily fermented, which may accelerate the subsequent AD process. Hence, to the best of our knowledge, the use of LD to neutralize alkali-pretreated CS for the initiation of AD is reported herein for the first time.

For alkali-treated materials immersed in liquids, gaseous $\mathrm{CO}_{2}$ or biogas has been previously utilized as an effective aid for alkali neutralization [18,19]. However, gasneutralization of CS with high TS content has not been investigated yet, as most of the pretreatment processes were seemingly carried out at high water content. To avoid generation and disposal of waste chemical solution, the use of limited water was considered to be a simpler, more cost-effective, and more environmentally friendly method [24]. In order to continue this idea of water conservation, it is necessary to explore the gas-neutralization under solid conditions.

To this end, the objectives of this study are: (1) to investigate the effect of LD on reducing $\mathrm{pH}$ of alkali-pretreated $\mathrm{CS}$; (2) to attempt $\mathrm{CO}_{2}$-neutralization in the substrate state with high TS content; and (3) to compare the applicability of the two methods for the thermophilic AD (liquid or solid state) of lignocellulosic feedstocks.

\section{Materials and Methods}

\subsection{Samples}

The employed CS was provided by a farm (Lianyungang, China). It was hammer milled through a 10-mesh sieve, and then stored in bags at room temperature for further use. The fermentative inoculum and LD were derived from a lab-scale $(30 \mathrm{~L})$ thermophilic $\left(55^{\circ} \mathrm{C}\right)$ semi-continuous L-AD digester that had been exclusively loaded with lignocellulosic biomass for $>2$ years to ensure high microbial activity. Prior to use, the previously stored substrate, freshly collected inoculum, and LD were determined to obtain the conventional physicochemical characteristics presented in Table 1.

\subsection{Lime Pretreatment}

In this work, lime pretreatment was carried out at a high solid-liquid ratio for water conservation. Every $100 \mathrm{~g}$ of CS (dry mass) was mixed with $300 \mathrm{~mL}$ of tap water and $8.0 \mathrm{~g}$ of $\mathrm{Ca}(\mathrm{OH})_{2}$ in a 5 -L flask at a loading rate of $8 \%\left(\mathrm{~g} \mathrm{Ca}(\mathrm{OH})_{2} / \mathrm{g}\right.$ initial TS of CS biomass). The mixture was transferred into foil pouches, sealed with thermoplastic, and stored at $30 \pm 1^{\circ} \mathrm{C}$ for 7 days. 
Table 1. Characteristics of materials.

\begin{tabular}{|c|c|c|c|}
\hline Parameters & Corn Stover & Inoculum & Liquid Digestate \\
\hline Total solids (\%) & $91.48 \pm 0.10$ & $13.54 \pm 0.05$ & $\mathrm{~N} / \mathrm{D}$ \\
\hline Volatile solids (\%) & $84.55 \pm 0.19$ & $6.51 \pm 0.04$ & $\mathrm{~N} / \mathrm{D}$ \\
\hline Total organic carbon (\%) & $43.11 \pm 0.77$ & $25.77 \pm 0.36$ & $\mathrm{~N} / \mathrm{D}$ \\
\hline Total nitrogen $(\%)$ & $1.02 \pm 0.03$ & $2.61 \pm 0.07$ & $0.15 \pm 0.00$ \\
\hline $\mathrm{C} / \mathrm{N}$ ratio & $42.28 \pm 0.74$ & $9.89 \pm 0.29$ & $\mathrm{~N} / \mathrm{D}$ \\
\hline Alkalinity $\left(\mathrm{g} \mathrm{CaCO}_{3} / \mathrm{kg}\right)$ & $8.54 \pm 0.02$ & $10.23 \pm 0.35$ & $1.87 \pm 0.11$ \\
\hline Cellulose $(\%)^{a}$ & $33.83 \pm 0.36$ & $\mathrm{~N} / \mathrm{D}$ & $\mathrm{N} / \mathrm{D}$ \\
\hline Hemicellulose (\%) ${ }^{a}$ & $26.10 \pm 0.33$ & $\mathrm{~N} / \mathrm{D}$ & $\mathrm{N} / \mathrm{D}$ \\
\hline $\operatorname{Lignin}(\%)^{a}$ & $19.10 \pm 0.89$ & $\mathrm{~N} / \mathrm{D}$ & $\mathrm{N} / \mathrm{D}$ \\
\hline $\operatorname{MLSS}(\mathrm{g} / \mathrm{L})$ & $\mathrm{N} / \mathrm{D}$ & $\mathrm{N} / \mathrm{D}$ & $3.72 \pm 0.13$ \\
\hline $\operatorname{MLVSS}(\mathrm{g} / \mathrm{L})$ & $\mathrm{N} / \mathrm{D}$ & $\mathrm{N} / \mathrm{D}$ & $2.64 \pm 0.14$ \\
\hline $\mathrm{pH}$ & $\mathrm{N} / \mathrm{D}$ & $7.87 \pm 0.08$ & $7.53 \pm 0.09$ \\
\hline
\end{tabular}

a Based on VS while the rest are based on total weight; N/D, not determined.

\subsection{Neutralization of Lime-Treated Corn Stover}

Neutralization with LD (LDN) was performed in $1 \mathrm{~L}$ plastic boxes. Mixtures of LD with lime-treated CS (wet mass) in different ratios $(v / w)$ were effective in reducing $\mathrm{pH}$, with 1:1 being the best (Supplementary Data Figure S1). So, in this section, every $200 \mathrm{~g}$ of lime-treated CS (wet mass) was mixed with $200 \mathrm{~mL}$ of LD at a loading ratio of $12.3 \%$ (TS of CS biomass). The plastic boxes were covered with fresh wraps and were further incubated at $30 \pm 1{ }^{\circ} \mathrm{C}$ for $60 \mathrm{~h}$ in triplicate. The samples were taken at 12 -h intervals to monitor the changes in $\mathrm{pH}$ and VFAs. The neutralized CS was then divided into two parts, one for $\mathrm{L}-\mathrm{AD}$ directly and the other for SS-AD after dehydration by extrusion to $25-28 \%$ TS.

Two influencing factors were examined in the $\mathrm{CO}_{2}$ neutralization $(\mathrm{CN})$ including $\mathrm{CO}_{2}$ concentration and moisture. The $100 \% \mathrm{CO}_{2}, 50 \% \mathrm{CO}_{2}$ (simulating biogas with methane replaced by nitrogen for safety reasons), $25 \%$ TS, or $9.1 \%$ TS were considered. More specifically, $160 \mathrm{~g}$ of lime-treated CS (wet mass) was fed into a $1 \mathrm{~L}$ plexiglass cylindrical vessel directly or mixed with $280 \mathrm{~mL}$ of distilled water. Subsequently, two separate concentrations of $\mathrm{CO}_{2}$ were purged from the bottom for $30 \mathrm{~min}$ at a flow rate of $0.2 \mathrm{~L} \mathrm{~min}^{-1}$. The $\mathrm{pH}$ was measured every $5 \mathrm{~min}$. For CS immersed in distilled water, the $\mathrm{pH}$ was measured directly; for CS in the solid state, $2 \mathrm{~g}$ of sample was taken and mixed with $20 \mathrm{~mL}$ of distilled water and shaken for $20 \mathrm{~min}$ before measurement. Afterward, the lime-treated $\mathrm{CS}$ was oven-dried at $105^{\circ} \mathrm{C}$ for $8 \mathrm{~h}$ and subsequently stored in a sealed plastic bag at $4{ }^{\circ} \mathrm{C}$ before digestion tests. $\mathrm{CN}$ was repeated three times.

The lime-treated CS was washed with tap water (WW) in $1 \mathrm{~L}$ plastic boxes until the $\mathrm{pH}$ decreased to 8.0 and then oven-dried at $105^{\circ} \mathrm{C}$ for $8 \mathrm{~h}$ and stored in a sealed plastic bag at $4{ }^{\circ} \mathrm{C}$ for future use. The characteristics of CS after performing the above three neutralizations were shown in Table S1 (Supplementary Data).

\subsection{Biomethane Potential Test}

To investigate the effect of the pre-operations on $\mathrm{CH}_{4}$ yield from $\mathrm{CS}$, a biomethane potential (BMP) test was conducted in triplicate bottles with a total volume of $500 \mathrm{~mL}$ and a working volume of $400 \mathrm{~mL}$. The parameter settings of the BMP test referred to some suggestions from Holliger et al. [25] and the results of some pre-experiments (Supplementary Data Figures S2 and S3). In particular, the inoculum injection was operated in the ratio of 1.6 (inoculum/substrate) on the basis of VS (volatile solids), and the substrate concentration was $12.5 \mathrm{gVS} / \mathrm{L}$. No additional nutrients or alkalinity was added. The headspace gas of each reactor was replaced with pure $\mathrm{N}_{2}$ before starting the test. The BMP test was additionally performed under the thermophilic conditions $\left(55^{\circ} \mathrm{C}\right)$ and intermittent stirring $(30 \mathrm{~s}$ clockwise, $30 \mathrm{~s}$ counterclockwise, and then $60 \mathrm{~s}$ rest in each cycle) for dozens of days until the daily methane yield was less than $1 \%$ of the total methane production. Microcrystalline cellulose was used as a positive control. 


\subsection{Batch Liquid Anaerobic Digestion Test}

The batch L-AD test was conducted in reactors with a total volume of $500 \mathrm{~mL}$ and a working volume of $400 \mathrm{~mL}$. The CS loading of each reactor was $50 \mathrm{~g}$ VS/L with reference to the previous settings [21], and then the inoculum was set at an S/I ratio of 4 (VS basis) based on the results of pre-experiments (Supplementary Data Figure S4). The same 400-mL working volume was adjusted by the extra addition of tap water, resulting in an initial TS concentration of $7.4-7.9 \%$. Briefly, based on VS, $20 \mathrm{~g}$ of substrate (treated with the three neutralization methods described above), $5 \mathrm{~g}$ of inoculum and some required water were added to a series reactors. Subsequently, the mixture was flushed with pure $\mathrm{N}_{2}$ for $5 \mathrm{~min}$ to remove $\mathrm{O}_{2}$, followed by incubation at $55^{\circ} \mathrm{C}$ for $30 \mathrm{~d}$. The same intermittent stirring parameters as in the BMP test were selected. Pure inoculum was applied as a control. All treatments were conducted in triplicate.

\subsection{Batch Solid-State Anaerobic Digestion Test}

The batch SS-AD test was established in 100-mL glass bottles without mechanical stirring or leachate recirculation. The S/I ratio was 6 (VS basis) [26] and the initial TS content was $20 \%$ [7]. To this end, $9 \mathrm{~g}$ of substrate treated with the three neutralization methods described above and $1.5 \mathrm{~g}$ of inoculum were thoroughly mixed on the basis of VS, and the initial TS levels were regulated by tap water. Then, about $65 \mathrm{~g}$ of the total mixture was added to the series of $100-\mathrm{mL}$ anaerobic reactors. Subsequently, the reactors were flushed with pure $\mathrm{N}_{2}$ for 5 min to provide an anaerobic environment and then fermented at $55^{\circ} \mathrm{C}$ for $30 \mathrm{~d}$. Pure inoculum was used as the control. All treatments were conducted in triplicate.

\subsection{Analytical Methods}

$\mathrm{CH}_{4}$ production was monitored daily using an automated methane potential testing system (RTK-BMP, Rocktek Instrument, Wuhan, China), which was normalized by converting the temperature and pressure to the standard state $\left(0{ }^{\circ} \mathrm{C}, 101.325 \mathrm{kPa}\right)$.

TS, VS, and alkalinity of the inoculum, CS, and LD were determined according to standard methods [27]. Total nitrogen concentrations were measured using a Kjeldahl analyzer (K99860, Hanon, Jinan, China). Total organic carbon was analyzed by a TOC Analyzer (Elementar, Vario TOC, Hannau, Germany). The lignocellulose content was determined using HPLC (1200, Agilent, Santa Clara, CA, USA) according to the analytical procedures provided by NREL [28]. To quantify VFAs, $2 \mathrm{~g}$ of sample (fresh matter) and $20 \mathrm{~mL}$ of distilled water were mixed and shaken for $20 \mathrm{~min}$, followed by centrifugation at $4000 \mathrm{rpm}$ for $5 \mathrm{~min}$, after which the $\mathrm{pH}$ of $4 \mathrm{~mL}$ supernatant was adjusted to 2-3 by formic acid and then measured using a GC system (7890A, Agilent, Santa Clara, CA, USA) equipped with a $30 \mathrm{~m} \times 0.32 \mathrm{~mm} \times 0.25 \mu \mathrm{m}$ DB-FFAP column and a flame ionization detector.

\subsection{Data Analyses}

The modified Gompertz equation was fitted to the measured cumulative $\mathrm{CH}_{4}$ production curves of L-AD and SS-AD, respectively, as shown in Equation (1) below, which was developed by Lay et al. [29]:

$$
\mathrm{P}(\mathrm{t})=\mathrm{P}_{\mathrm{m}} \cdot \exp \left\{-\exp \left[\frac{\mathrm{R}_{\mathrm{m}} \cdot \mathrm{e}}{\mathrm{P}_{\mathrm{m}}}(\lambda-\mathrm{t})+1\right]\right\}
$$

where $\mathrm{P}(\mathrm{t})$ is the cumulative $\mathrm{CH}_{4}$ production $\left(\mathrm{mL}_{\mathrm{N}}\right)$ at time $\mathrm{t}, \mathrm{P}_{\mathrm{m}}$ is the maximum $\mathrm{CH}_{4}$ potential $\left(\mathrm{mL}_{\mathrm{N}}\right)$ at the end of incubation time, $t$ is time $(\mathrm{d}), \mathrm{R}_{\mathrm{m}}$ is the maximum $\mathrm{CH}_{4}$ production rate $\left(\mathrm{mL}_{\mathrm{N}} \cdot \mathrm{d}^{-1}\right), \lambda$ is the lag phase $(\mathrm{d})$, and $\mathrm{e}$ is the base of natural logarithms, that is, 2.71828. The three parameters $P_{m}, R_{m}$, and $\lambda$ were estimated using the nonlinear curve fit program in the GraphPad Prism 8.0.1 software (GraphPad Software, San Diego, CA, USA, 2018).

Standard deviations and statistical differences were analyzed using the GraphPad Prism 8.0.1 software. All figures in this manuscript were also created using the above software. 


\section{Results and Discussion}

\subsection{Reduction in $\mathrm{pH}$ and Accumulation of Volatile Fatty Acids during Liquid Digestate Neutralization}

The LDN process significantly $(p<0.05)$ reduced the $\mathrm{pH}$ from 9.3 to 7.5 during $60 \mathrm{~h}$ (Figure 1a), indicating that the method could effectively decrease the $\mathrm{pH}$ of the alkalitreated CS. There were two drivers behind this reduction. First, the direct and immediate neutralization reaction caused the $\mathrm{pH}$ of the lime-treated $\mathrm{CS}$ to drop from approximately 10.5 to 9.3 during the mixing process at $0 \mathrm{~h}$ (omitted from Figure 1). Second, the LD contained sufficient acid-producing microbes to further reduce the $\mathrm{pH}$ by continued acid production during subsequent incubation. Notably, LD arguably contains not only acid producers but also acid consumers. However, the LDN process was carried out under nonstrictly anaerobic and overloaded conditions, which were not conducive to the activity of acid-consuming microorganisms, thus, breaking the imbalance between the acid production and consumption rate $[30,31]$. Consequently, we utilized this imbalance to decrease the $\mathrm{pH}$ and stopped it in time. This was also conductive to avoid over-acidification, which could affect the subsequent $\mathrm{AD}$.
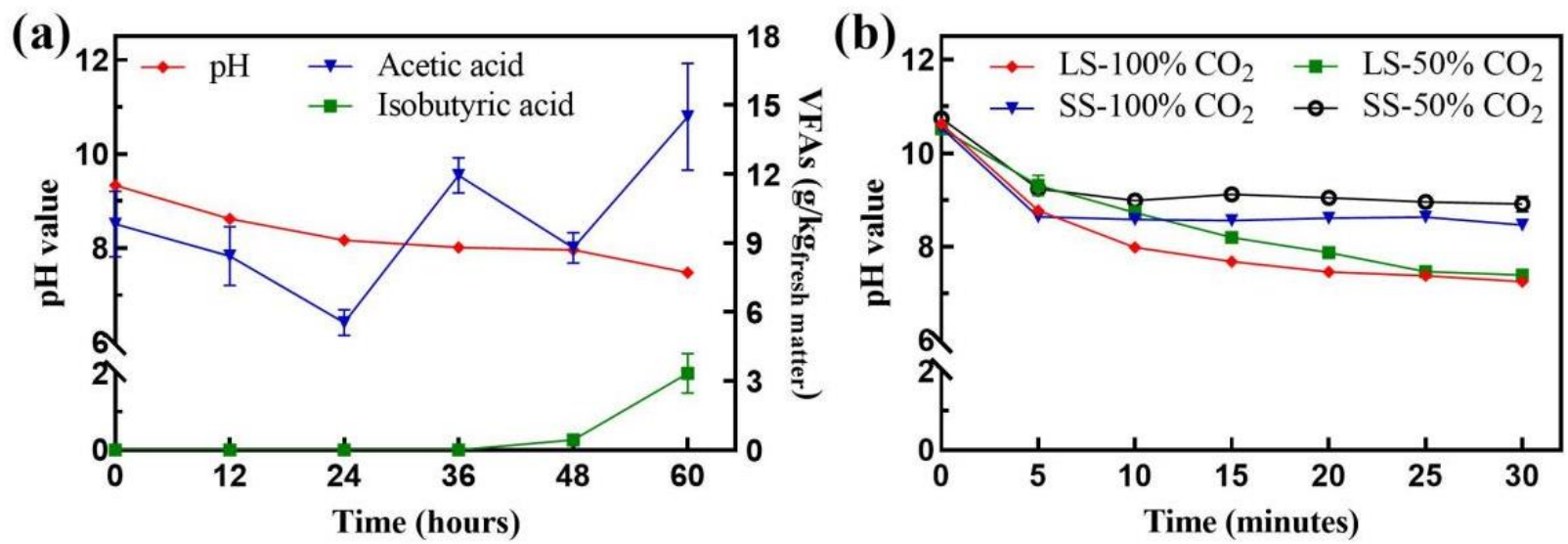

Figure 1. Changes in (a) $\mathrm{pH}$ and VFAs during LD-neutralization; and (b) $\mathrm{pH}$ during $\mathrm{CO}_{2}$-neutralization. LS- and SS-denote liquid state and solid state, respectively. Data are shown as mean \pm standard deviation (SD), $n=3$.

As shown in Figure 1a, a certain amount of acetic acid appeared at $0 \mathrm{~h}$, which was one of the by-products generated during the alkali treatment process [32]. Acetic acid first decreased gradually from 9.8 to $5.5 \mathrm{~g} / \mathrm{kg}_{\text {fresh matter }}$ within $24 \mathrm{~h}$, then gradually accumulated and finally reached $14.5 \mathrm{~g} / \mathrm{kg}_{\text {fresh matter }}$ at $60 \mathrm{~h}$. As for isobutyric acid, it started appearing after $36 \mathrm{~h}$, and finally reached up to $3.3 \mathrm{~g} / \mathrm{kg}_{\text {fresh matter }}$ at $60 \mathrm{~h}$. Surprisingly, no accumulation of propionic, n-butyric, and valeric acid was identified throughout the process. This finding contradicts the previous reports on over-acidification $[30,33]$, seemingly because the $\mathrm{pH}$ of the LDN process did not drop to 6.5, or even lower, as typically observed in the case of over-acidification. The production of these VFAs was responsible for the reduction in $\mathrm{pH}$, but it is worth noting that the drop followed by the rise in acetic acid implied that part of the biomass that could have produced biogas in the future was inevitably metabolized by these acid consumers. To avoid excessive biomass loss during $\mathrm{pH}$ reduction, the effect of different $\mathrm{pH}$ endpoints neutralized by $\mathrm{LD}$ on the cumulative/daily methane production has been compared in BMP tests with lime-treated CS and pH 7.6 was finally chosen as the endpoint for LDN (Supplementary Data Figure S5).

\subsection{Reduction in $\mathrm{pH}$ during Gas-Neutralization}

As seen from Figure 1b, after $30 \mathrm{~min}$ of $100 \% \mathrm{CO}_{2}$-neutralization, the $\mathrm{pH}$ of limetreated CS decreased significantly $(p<0.05)$ from 10.5 to 8.5 (solid-state condition) and 7.3 (liquid-state condition), respectively. In particular, the $\mathrm{pH}$ of the CS in the solid condition nearly stopped changing from the 5th min onwards, while the $\mathrm{pH}$ of the CS in 
the liquid condition had been further continuously decreasing over the observed time range, despite the trend becoming increasingly slow. By comparison, it has been reported that $100 \% \mathrm{CO}_{2}$-neutralization in the liquid state can reduce the $\mathrm{pH}$ to 6.8 and 7.0 , respectively $[18,34]$. This is probably because the alkali-treated lignocellulose releases alkaline substances more easily after immersion in water, and $\mathrm{CO}_{2}$ dissolved in it completes the acid-base neutralization reaction.

Figure $1 \mathrm{~b}$ illustrates the results of $50 \% \mathrm{CO}_{2}$-neutralization. A similar phenomenon to those mentioned above with a slightly less effective $\mathrm{pH}$ reduction was identified. For the liquid condition, nearly the same $\mathrm{pH}$ endpoint was shown $(p>0.05)$, but the slope changed more slowly, while for the solid state, the $\mathrm{pH}$ endpoint was higher, approximately $8.9(p<0.05)$. This finding indicates that the simulated biogas (containing $50 \% \mathrm{CO}_{2}$ ) was not suitable for neutralization reactions under solid-state conditions.

To the best of our knowledge, the $\mathrm{CO}_{2}$-neutralization process under solid-state conditions was used for the first time. Although the final lower $\mathrm{pH}$ limit was higher than that of the liquid method reported earlier by other studies, it still meets the requirements for the $\mathrm{AD}$ initiation if operated with $100 \% \mathrm{CO}_{2}$. It was also more convenient for SS-AD as no additional water was required.

\subsection{Effect of Neutralization on Biomethane Potential Test}

The purpose of the BMP test was to investigate the effects of different treatments on the biomethane potential. As shown in Figure 2a, the curves have a similar trend. And Figure $2 \mathrm{~b}$ displays that the total methane yield for raw material $(\mathrm{RM})$ was $218.9 \mathrm{~mL}_{\mathrm{N}} \cdot \mathrm{gVS}_{\text {feed }}{ }^{-1}$ whereas it was $267.3,253.7$, and $221.6 \mathrm{~mL}_{\mathrm{N}} \cdot \mathrm{gVS}_{\text {feed }}{ }^{-1}$ for neutralization with $\mathrm{WW}, \mathrm{CN}$, and LDN, respectively. The total methane yield of WW was the highest, seemingly due to a large amount of water washing that removed the non-fermentable inert components (e.g., lignin) from VS. This yielded the highest percentage of fermentability, while causing the large amounts of wastewater at the same time. There was no significant difference $(p>0.05)$ between $\mathrm{CN}$ and LDN, but LDN was slightly lower than $\mathrm{CN}$, seemingly because the acid consumers from the LD triggered a part of the loss of methane potential during the $\mathrm{pH}$ reduction process.
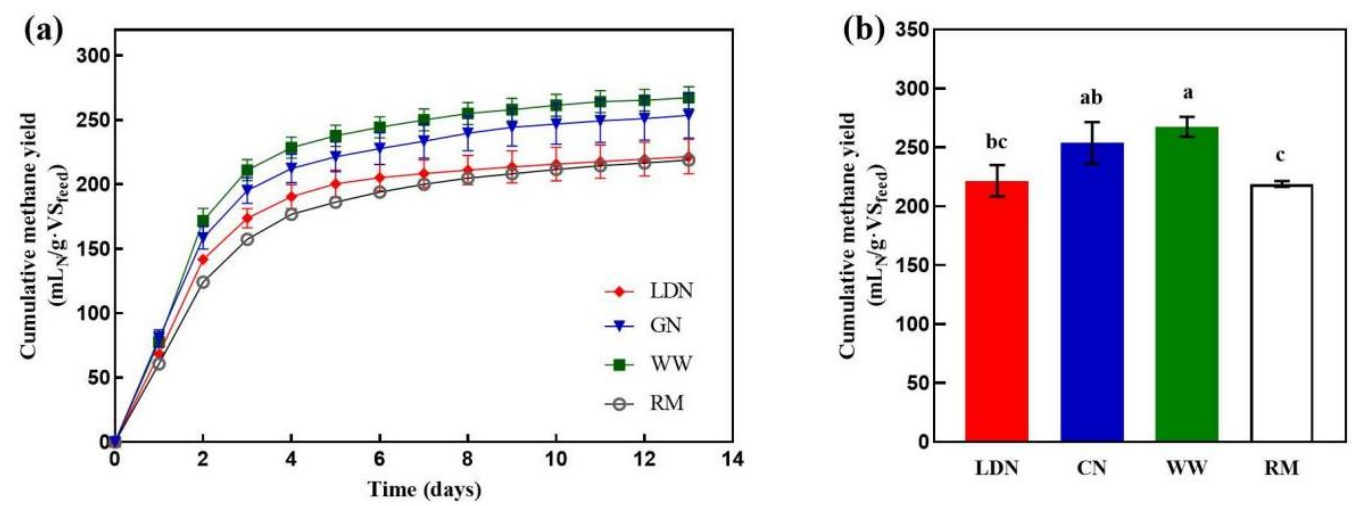

Figure 2. Effect of different neutralization treatments on BMP tests of lime-treated corn stover: (a) cuvers and (b) total yields. Data are shown as mean $\pm \mathrm{SD}, n=3$. Significant differences are indicated by different letters $(p<0.05)$.

Overall, these results suggest that different neutralization methods have different degrees of impact on the biomethane potential of CS. Compared to RM, 22.11\% and 15.90\% improvements were identified for WW and $\mathrm{CN}$, respectively. The increase in methane production was associated with the lime pretreatment $[15,35,36]$, but the difference in the degree of improvement emerged because the washing process had inevitably concentrated the fermentable fraction. Alas, LDN, with the drag of the acid consumers, completely diminished the increase caused by lime pretreatment. 


\subsection{Effect of Neutralization on Thermophilic Liquid Anaerobic Digestion}

To explore the applicability of different neutralization treatments for thermophilic L$\mathrm{AD}$, the cumulative methane yields and daily methane yields of the reactors are presented in Figure 3. The cumulative methane yields of all reactors with different neutralization treatments ranged between $186.7-225.3 \mathrm{~mL}_{\mathrm{N}} \cdot \mathrm{gVS}_{\text {feed }}{ }^{-1}$, while the $\mathrm{CN}$ had the highest yield with a significant $(p<0.05)$ increase of $20.6 \%$ over that of RM. However, the peak of $\mathrm{CN}^{\prime}$ 's daily methane production occurred the latest, on day 6, even 2 days later than that of RM. Jiang et al. [15] did not find any AD initiation lag when using lime for pretreatment, seemingly because they removed the fermentation inhibitors by washing with water, while $\mathrm{CO}_{2}$ neutralization did not. The inhibitors were derived from the side products released during the lignocellulosic pretreatment process, and they can have a negative impact on the enzymatic activity, growth, and metabolism of the microbial community associated with the AD process [37]. Similarly to the BMP test, the cumulative methane production of LDN was not significantly $(p>0.05)$ different from that of RM. Hu et al. [20] found that LD would cause the consumption of soluble substrate, which could explain our experimental results. However, the earliest peak in the daily methane production of all reactors was observed at LDN, likely due to the destructive effect of microorganisms in the LD on the dense structure of the CS, which was confirmed by a previous report [21].
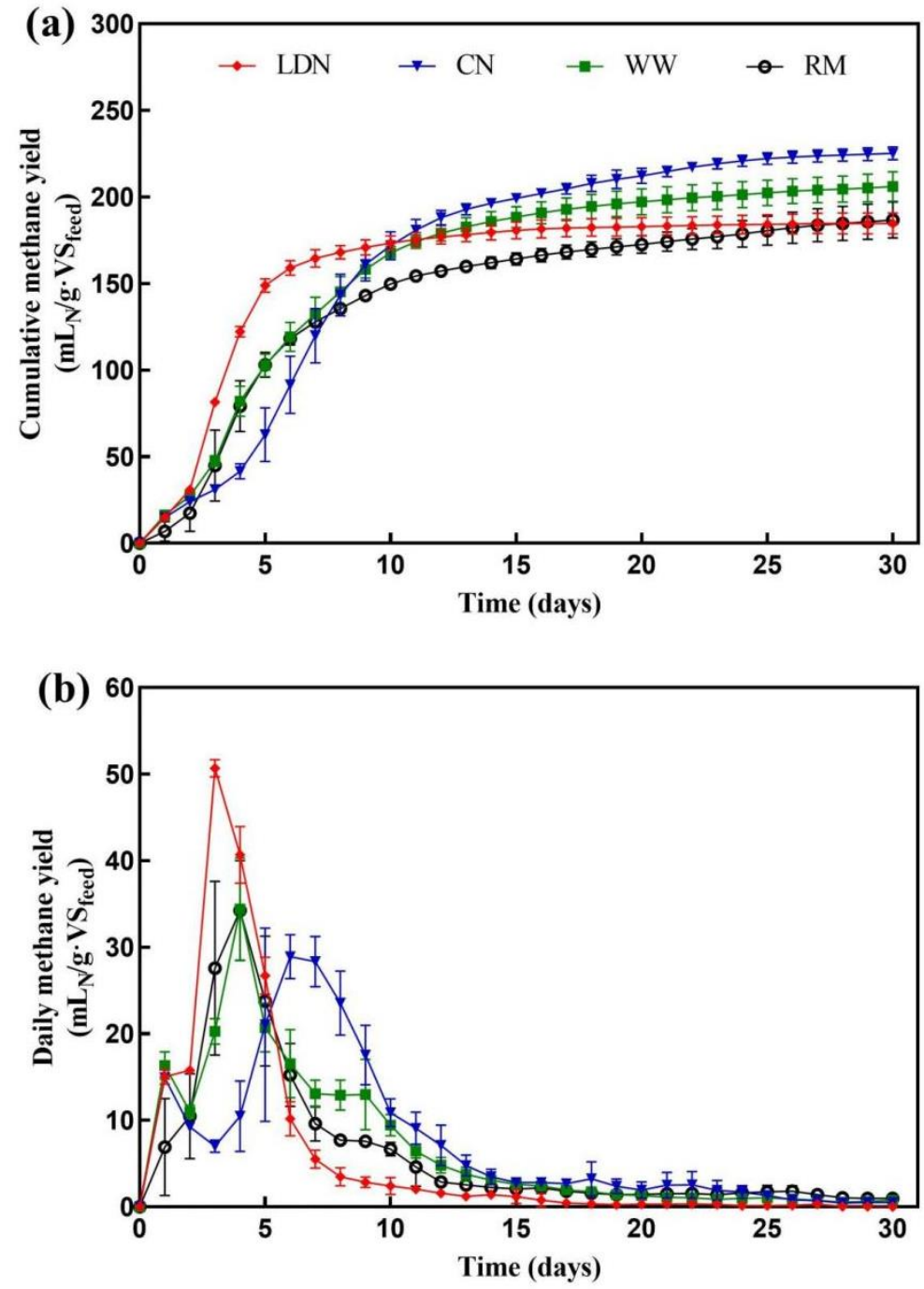

Figure 3. Effect of different neutralization treatments on the (a) cumulative methane yield; and (b) daily methane yield during 30 days thermophilic L-AD of lime-treated corn stover. Data are shown as mean $\pm \mathrm{SD}, n=3$. 


\subsection{Effect of Neutralization on Thermophilic Solid-State Anaerobic Digestion}

The cumulative methane yields and daily methane yields of the reactors for $30 \mathrm{~d}$ for thermophilic SS-AD are shown in Figure 4. The cumulative methane yields of all reactors with different neutralization treatments ranged between $23.1-232.7 \mathrm{~mL}_{\mathrm{N}} \cdot \mathrm{gVS}_{\text {feed }}{ }^{-1}$. Meanwhile, the reactors treated by WW had much lower cumulative methane yield of $23.1 \mathrm{~mL}_{\mathrm{N}} \cdot \mathrm{gVS}_{\text {feed }}{ }^{-1}$, which was approximately $88-90 \%$ less compared with reactors treated by others and RM (see Figure 4a). In fact, the cumulative methane yield of the WW treatment nearly halted from the 9th day (Figure $4 b$ ), thereby exhibiting a typical acidification phenomenon, which was confirmed by the measurement of $\mathrm{pH}(<5.8)$ on day 30 . In the experiments described herein, a large amount of tap water was consumed to lower the $\mathrm{pH}$ of the lime-treated CS to 8.0, which could simultaneously reduce the alkalinity of the substrate. At the same time, our experiments were performed at lower inoculation ratios ( $\mathrm{S} / \mathrm{I}=6$, VS basis) compared to those reported for SS-AD at an S/I of 1-4 [38,39], which further increased the risk of over-acidification. Moreover, AD of WW has not failed both in the BMP test and the L-AD, seemingly due to the higher ratio of inoculum, lower TS, and intermittent physical stirring providing many microbes and a more efficient mass transfer environment.
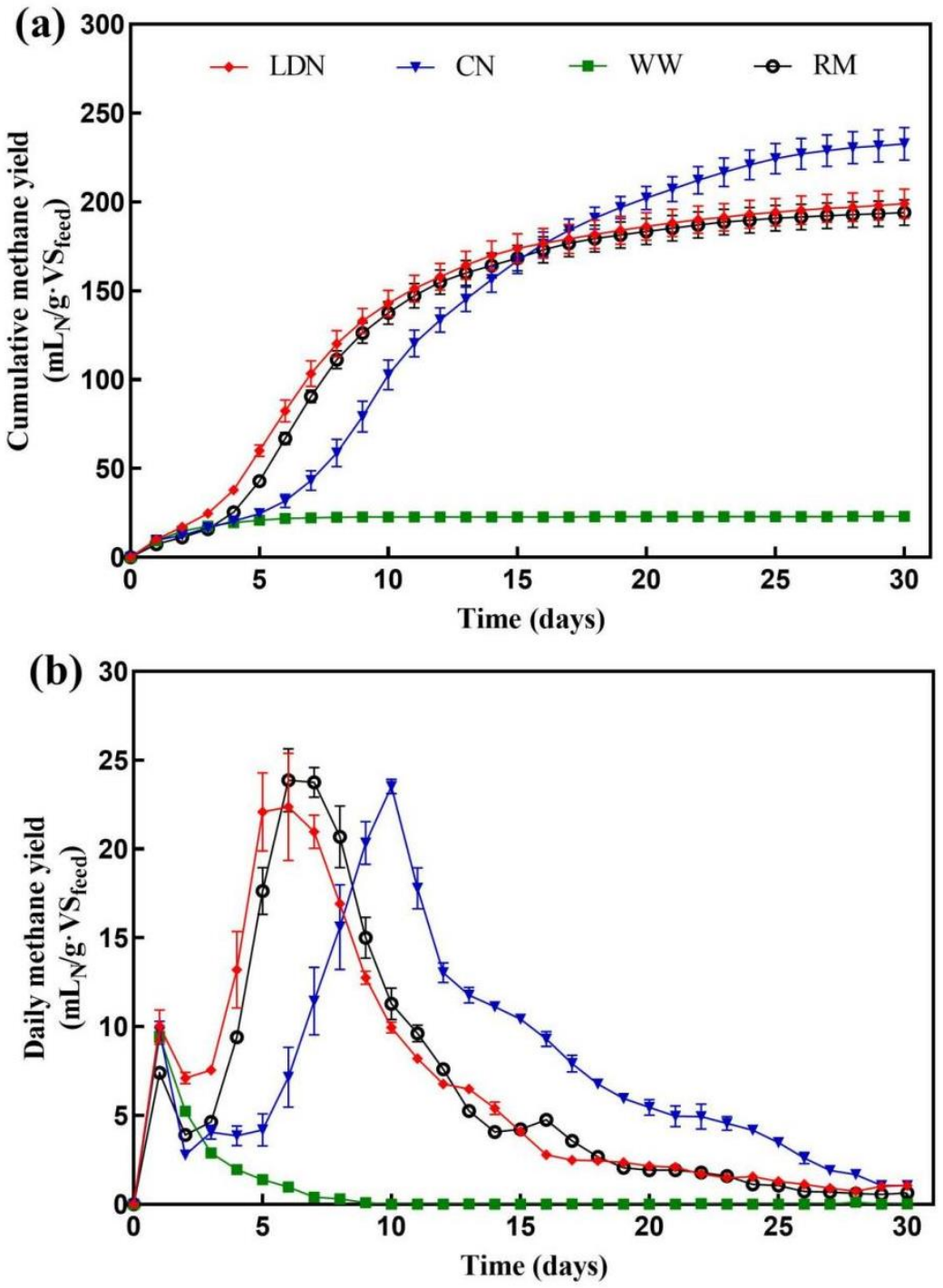

Figure 4. Effect of different neutralization treatments on the (a) cumulative methane yield; and (b) daily methane yield during 30 days thermophilic SS-AD of lime-treated corn stover. Data are shown as mean $\pm \mathrm{SD}, n=3$. 
Compared to RM, the cumulative methane yield of $\mathrm{CN}$ was significantly $(p<0.05)$ increased by $19.9 \%$. Li et al. [7] also achieved higher methane yields when using $\mathrm{NaOH}$ for pretreatment, which was a larger increase $(40.1 \%)$ than that in this study because Li et al. used a smaller size of corn stover as a substrate for AD. Moreover, the peak of $\mathrm{CN}^{\prime}$ s daily methane yield was delayed by four days (Figure $4 \mathrm{~b}$ ). In contrast, the peak of daily methane yield of LDN was 1 and 5 days earlier than that of RM and CN, respectively (Figure $4 b$ ). This finding can be potentially explained by the fact that the microorganisms in LD facilitate the disruption of the dense structure of CS. At the same time, the inhibition of the AD process driven by the pretreatment by-products disappeared, probably because the extrusion step had removed some of the by-products, thereby resulting in the concentrations of these inhibitors below the threshold of inhibition. However, the extrusion step removed not only the fermentation inhibitors but also the dissolved fermentable fractions, so that the cumulative methane yield was not significantly different from that of RM (Figure 4a).

\subsection{Kinetics of the Anaerobic Digestion Process}

The modified Gompertz equation was applied to fit the cumulative biomethane production of the BMP test and thermophilic L- and SS-AD, and the simulation results are displayed in Figure 5 as well as in Table 2. The fitting index $\left(R^{2}\right)$ values ranged from 0.9632 to 0.9975 , indicating that the modified Gompertz equation was applicable not only to the BMP test and thermophilic L-AD but also SS-AD without stirring. The lowest $\mathrm{R}^{2}(0.9632)$ was WW-SS (WW for SS-AD) because it failed to initiate AD due to acidification. Moreover, the different treatments caused variations in $R_{m}, \lambda$, and $P_{m}$, which were in accordance with the daily and cumulative methane yields (see Figures 3 and 4 for details).

Table 2. Kinetic parameters of biomethane production with the modified Gompertz model.

\begin{tabular}{|c|c|c|c|c|}
\hline Method & $R_{m}\left(m L_{N} \cdot d^{-1}\right)$ & $\lambda(\mathrm{d})$ & $P_{m}\left(m_{N}\right)$ & $\mathbf{R}^{2}$ \\
\hline $\mathrm{LDN}^{-\mathrm{B}^{\mathrm{a}}}$ & 364.8 & 0.1 & 1065.6 & 0.9897 \\
\hline $\mathrm{CN}-\mathrm{B}^{\mathrm{a}}$ & 385.0 & 0.0 & 1210.7 & 0.9827 \\
\hline WW-B ${ }^{a}$ & 445.1 & 0.1 & 1283.2 & 0.9870 \\
\hline RM-B ${ }^{a}$ & 286.2 & 0.0 & 1045.8 & 0.9842 \\
\hline LDN-L ${ }^{b}$ & 721.0 & 1.1 & 3108.2 & 0.9942 \\
\hline $\mathrm{CN}-\mathrm{L}^{\mathrm{b}}$ & 453.2 & 1.8 & 4398.6 & 0.9946 \\
\hline WW-L ${ }^{b}$ & 431.8 & 0.6 & 4010.2 & 0.9955 \\
\hline RM-L b & 432.3 & 0.8 & 3513.9 & 0.9832 \\
\hline LDN-SS $^{\mathrm{c}}$ & 163.9 & 1.6 & 1744.2 & 0.9962 \\
\hline CN-SS ${ }^{\mathrm{C}}$ & 143.9 & 3.9 & 2128.1 & 0.9975 \\
\hline WW-SS c & 58.9 & -0.2 & 205.1 & 0.9632 \\
\hline RM-SS c & 172.8 & 2.5 & 1708.5 & 0.9962 \\
\hline
\end{tabular}

${ }^{a}$ BMP test with $5 \mathrm{~g}$ of substrate (VS basis). ${ }^{\mathrm{b}}$ Liquid anaerobic digestion with $9 \mathrm{~g}$ of substrate (VS basis)

${ }^{\mathrm{c}}$ Solid-state anaerobic digestion with $20 \mathrm{~g}$ of substrate (VS basis).

\subsection{Economic Evaluation Analysis}

In this study, a simple economic evaluation analysis (Table 3) for the three neutralization methods was performed using the Engineering Economics Analysis method [21]. The price of pretreatment reagents, water, wastewater treatment and methane were achieved according to current market price, the average industrial water price, the average industrial wastewater treatment cost and the average liquefied natural gas (LNG) price in October 2021 in China, respectively (Lime is $944.44 \mathrm{RMB} / \mathrm{t}$, $\mathrm{LDN}$ is $0.00 \mathrm{RMB} / \mathrm{t}, \mathrm{CN}$ is $0.00 \mathrm{RMB} / \mathrm{t}$, industrial water is $4.1 \mathrm{RMB} / \mathrm{t}$, industrial wastewater treatment is $2.00 \mathrm{RMB} / \mathrm{t}$ and the methane price is $4.88 \mathrm{RMB} / \mathrm{m}^{3}$ ). The profit value was calculated based on the $\mathrm{RM}$, so there was no additional calculation of cost consumption which were the same (e.g., labor costs, energy costs, CS costs, depreciation costs of the instruments and equipment, costs of use-and-throw materials). The net profit was defined as the energy revenue from the methane production minus the cost of starting material. 

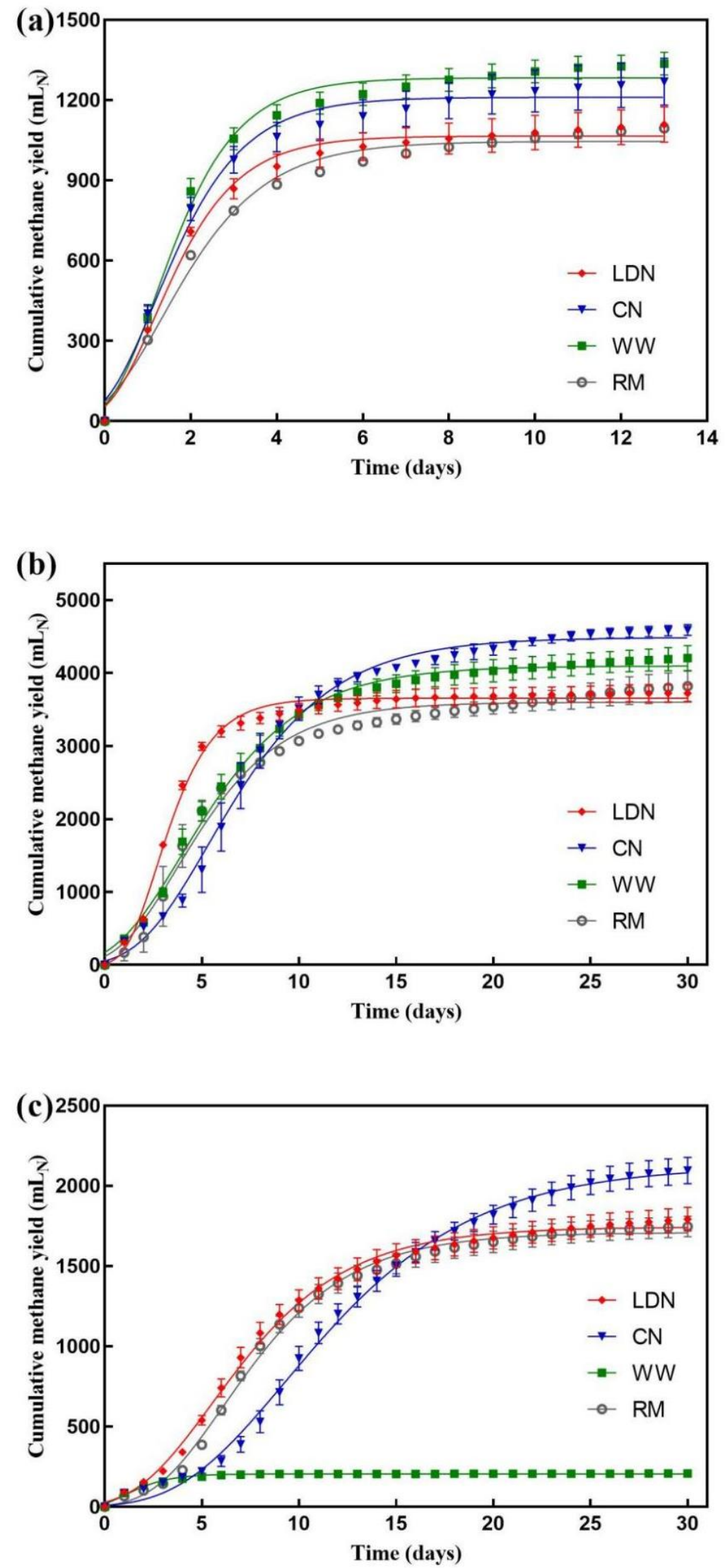

Figure 5. Curve fitting of the Gompertz equation to methane production data for (a) BMP, (b) L-AD and (c) SS-AD tests. Dots denote the means of data and lines denote the Gompertz curves. 
Table 3. Economic evaluation of different neutralization methods for lime-pretreated corn stover.

\begin{tabular}{|c|c|c|c|c|c|}
\hline Iterms & $\begin{array}{c}\text { Lime } \\
\text { Pretreatment } \\
\text { Reagent and } \\
\text { Water Cost } \\
\left(\mathrm{RMB} / \mathrm{TS}^{\mathrm{a}}\right)\end{array}$ & $\begin{array}{l}\text { Neutralization } \\
\text { Cost } \\
\left(\mathrm{RMB} / \mathrm{TS}^{\mathrm{a}}\right)\end{array}$ & $\begin{array}{l}\text { Wastewater } \\
\text { Treatment } \\
\text { Cost } \\
\text { (RMB/t TS a) }\end{array}$ & $\begin{array}{c}\text { Methane } \\
\text { Profits } \\
\text { (RMB/t TS }{ }^{\text {a) }}\end{array}$ & $\begin{array}{l}\text { Net Profits } \\
\left(\mathrm{RMB} / \mathrm{t} \mathrm{TS}^{\mathrm{a}}\right)\end{array}$ \\
\hline $\mathrm{LDN}^{-\mathrm{L}^{\mathrm{b}}}$ & 87.41 & 0.00 & 0.00 & -9.33 & -96.74 \\
\hline CN-L b & 87.41 & 0.00 & 0.00 & 188.30 & 100.89 \\
\hline WW-L b & 87.41 & 82.00 & 40.00 & 94.37 & -126.89 \\
\hline RM-L b & - & - & - & - & - \\
\hline LDN-SS $^{\mathrm{c}}$ & 87.41 & 0.00 & 0.00 & 24.72 & -62.69 \\
\hline $\mathrm{CN}^{-S S}{ }^{\mathrm{c}}$ & 87.41 & 0.00 & 0.00 & 186.15 & 98.74 \\
\hline WW-SS ${ }^{c}$ & 87.41 & 82.00 & 40.00 & -835.10 & -1056.36 \\
\hline RM-SS c & - & - & - & - & - \\
\hline
\end{tabular}

${ }^{a}$ Based on initial TS of corn stover biomass. ${ }^{b}$ Liquid anaerobic digestion. ${ }^{c}$ Solid-state anaerobic digestion.

For all neutralization methods, the cost of the lime pretreatment reagent and water in the first step was the same (87.41 RMB/t TS). The total cost of LDN and CN was $0.00 \mathrm{RMB} / \mathrm{t}$ TS, which was collected for free. The total cost of WW was $122.00 \mathrm{RMB} / \mathrm{t}$ TS, of which $82.00 \mathrm{RMB} / \mathrm{t}$ TS was used for neutralization and $40.00 \mathrm{RMB} / \mathrm{t}$ TS for wastewater treatment. $\mathrm{LDN}$ and $\mathrm{CN}$ were more advantageous in terms of cost compared to WW. However, among the three neutralization methods, the net profit of $\mathrm{CN}$ was the only positive one with 100.89 and $98.74 \mathrm{RMB} / \mathrm{t}$ TS in L-AD and SS-AD, respectively. Therefore, CN was more economically attractive for practical applications.

\section{Conclusions}

Two novel neutralization methods for lime-treated CS were developed for biomethane production: (1) LD-neutralization and (2) $\mathrm{CO}_{2}$-neutralization. Compared to other processes, they do not require a washing step, and both the $\mathrm{LD}$ and $\mathrm{CO}_{2}$ are by-products of $\mathrm{AD}$. This saves the cost of additional chemical agents. They all succeeded in reducing the $\mathrm{pH}$ to the fermentable range and $\mathrm{CN}$ was quicker. Moreover, $\mathrm{LDN}$ facilitated $\mathrm{AD}$ performance in terms of gas production rate, particularly in L-AD. However, it had a significant reduction in total biomethane yield compared to $\mathrm{CN}$, resulting in a negative net profit, which has entirely counterbalanced its advantage of the production rate. Furthermore, CN exhibited the highest gas production and net profit not only in L-AD but also in SS-AD, but with the disadvantage of the longest stagnation phase. Overall, this study provided references for adjusting the initial $\mathrm{pH}$ of lime-treated $\mathrm{CS}$ before $\mathrm{AD}$, and $\mathrm{CO}_{2}$-neutralization is recommended as a more efficient and affordable method.

Supplementary Materials: The following are available online at https://www.mdpi.com/article/10 .3390 /app112210884/s1, Figure S1: Changes in pH during liquid digestate (LD) neutralization at different ratios $(v / w)$ of LD to lime-treated corn stover (wet mass). Data are shown as mean \pm standard deviation (SD), $n=3$. Figure S2: Effect of I/S ratio on BMP test of microcrystalline cellulose. Data are shown as mean \pm standard deviation (SD), $n=3$. Figure S3: Effect of temperature on $\mathrm{BMP}$ test of microcrystalline cellulose. Data are shown as mean \pm standard deviation (SD), $n=3$. Figure S4: Effect of different S/I ratios on L-AD. Data are shown as mean \pm standard deviation (SD), $n=3$. Figure S5: Effect of different $\mathrm{pH}$ endpoints neutralized by LD on the cumulative/daily methane yield during BMP tests of lime-treated corn stover. Data are shown as mean $\pm \mathrm{SD}, n=3$. Table S1: Characteristics of CS after performing different neutralization before AD.

Author Contributions: Conceptualization, L.X. and Y.L.; methodology, L.X. and Y.L.; formal analysis, L.X.; investigation, L.X. and M.Y.; resources, S.Z.; data curation, L.X. and M.Y.; writing-original draft preparation, L.X. and Y.L.; writing-review and editing, L.X. and Y.L.; visualization, L.X. and D.H.; supervision, Y.M.; project administration, Y.L.; funding acquisition, Y.L. and Y.M. All authors have read and agreed to the published version of the manuscript. 
Funding: This work was supported by the Key Research and Development Program of Hubei Province, China (Grant No. 2020BAB095) and Fundamental Research Funds for the Central Universities of China (Grant No. 2662021FW006).

Institutional Review Board Statement: Not applicable.

Informed Consent Statement: Not applicable.

Data Availability Statement: Not applicable.

Acknowledgments: We gratefully acknowledge Yaohao Dun and Weiwei Dong for their valuable guidance and support.

Conflicts of Interest: The authors declare no conflict of interest. The funders had no role in the study's design; in the collection, analyses or interpretation of data; in the writing of the manuscript, or in the decision to publish the results.

$\begin{array}{ll}\text { Nomenclature } \\ \text { AD } & \begin{array}{l}\text { anaerobic digestion } \\ \mathrm{CN}\end{array} \\ \mathrm{CO} \text { neutralization } \\ \mathrm{C} / \mathrm{N} \text { ratio } & \begin{array}{l}\text { carbon/nitrogen ratio } \\ \text { corn stover }\end{array} \\ \mathrm{CS} & \text { inoculum/substrate ratio } \\ \text { I/S ratio } & \text { liquid anaerobic digestion } \\ \text { L-AD } & \text { Liquid digestate } \\ \text { LD } & \text { liquid digestate neutralization } \\ \text { LDN } & \text { substrate/inoculum ratio } \\ \text { S/I ratio } & \text { solid-state anaerobic digestion } \\ \text { SS-AD } & \text { total solids } \\ \text { TS } & \text { volatile fatty acids } \\ \text { VFAs } & \text { volatile solids } \\ \text { VS } & \text { washed with tap water } \\ \text { WW } & \end{array}$

\section{References}

1. Sun, H.; Cui, X.; Stinner, W.; Shah, G.M.; Cheng, H.; Shan, S.; Guo, J.; Dong, R. Synergetic effect of combined ensiling of freshly harvested and excessively wilted maize stover for efficient biogas production. Bioresour. Technol. 2019, 285, 121338. [CrossRef]

2. Bhatia, P.; Fujiwara, M.; Salangsang, M.; Qian, J.; Liu, X.; Ban, S.; Myojin, M.; Toda, T. Effect of Semi-Continuous Anaerobic Digestion on the Substrate Solubilisation of Lignin-Rich Steam-Exploded Ludwigia grandiflora. Appl. Sci. 2021, 11, 4452. [CrossRef]

3. Momayez, F.; Karimi, K.; Taherzadeh, M.J. Energy recovery from industrial crop wastes by dry anaerobic digestion: A review. Ind. Crops Prod. 2019, 129, 673-687. [CrossRef]

4. Shi, J.; Wang, Z.; Stiverson, J.; Yu, Z.; Li, Y. Reactor performance and microbial community dynamics during solid-state anaerobic digestion of corn stover at mesophilic and thermophilic conditions. Bioresour. Technol. 2013, 136, 574-581. [CrossRef]

5. Kasinski, S. Mesophilic and Thermophilic Anaerobic Digestion of Organic Fraction Separated during Mechanical Heat Treatment of Municipal Waste. Appl. Sci. 2020, 10, 2412. [CrossRef]

6. Yang, L.; Xu, F.; Ge, X.; Li, Y. Challenges and strategies for solid-state anaerobic digestion of lignocellulosic biomass. Renew. Sustain. Energy Rev. 2015, 44, 824-834. [CrossRef]

7. Li, Y.; Zhang, R.; He, Y.; Liu, X.; Chen, C.; Liu, G. Thermophilic Solid-State Anaerobic Digestion of Alkaline-Pretreated Corn Stover. Energy Fuels 2014, 28, 3759-3765. [CrossRef]

8. Rusin, J.; Chamradova, K.; Grycova, B. The influence of biomass agitation on biogas and methane production using the high-solids thermophilic anaerobic digestion. Green Process. Synth. 2017, 6, 273-279. [CrossRef]

9. Meng, L.; Xie, L.; Riya, S.; Terada, A.; Hosomi, M. Impact of turning waste on performance and energy balance in thermophilic solid-state anaerobic digestion of agricultural waste. Waste Manag. 2019, 87, 183-191. [CrossRef]

10. Soltanian, S.; Aghbashlo, M.; Almasi, F.; Hosseinzadeh-Bandbafha, H.; Nizami, A.-S.; Ok, Y.S.; Lam, S.S.; Tabatabaei, M. A critical review of the effects of pretreatment methods on the exergetic aspects of lignocellulosic biofuels. Energy Convers. Manag. 2020, 212, 112792. [CrossRef]

11. Xu, H.; Li, B.; Mu, X. Review of Alkali-Based Pretreatment to Enhance Enzymatic Saccharification for Lignocellulosic Biomass Conversion. Ind. Eng. Chem. Res. 2016, 55, 8691-8705. [CrossRef]

12. You, Z.; Zhang, S.; Kim, H.; Chiang, P.-C.; Sun, Y.; Guo, Z.; Xu, H. Effects of Corn Stover Pretreated with NaOH and CaO on Anaerobic Co-Digestion of Swine Manure and Corn Stover. Appl. Sci. 2018, 9, 123. [CrossRef]

13. Du, J.; Qian, Y.; Xi, Y.; Lü, X. Hydrothermal and alkaline thermal pretreatment at mild temperature in solid state for physicochemical properties and biogas production from anaerobic digestion of rice straw. Renew. Energy 2019, 139, 261-267. [CrossRef] 
14. Shen, J.; Zheng, Q.; Zhang, R.; Chen, C.; Liu, G. Co-pretreatment of wheat straw by potassium hydroxide and calcium hydroxide: Methane production, economics, and energy potential analysis. J. Environ. Manag. 2019, 236, 720-726. [CrossRef]

15. Jiang, D.; Ge, X.; Zhang, Q.; Zhou, X.; Chen, Z.; Keener, H.; Li, Y. Comparison of sodium hydroxide and calcium hydroxide pretreatments of giant reed for enhanced enzymatic digestibility and methane production. Bioresour. Technol. 2017, 244, 1150-1157. [CrossRef] [PubMed]

16. Sympson, W.; Nokes, S.; Hickman, A. Recirculating calcium hydroxide solution: A practical choice for on-farm high solids lignocellulose pretreatment. Ind. Crops Prod. 2017, 97, 492-497. [CrossRef]

17. Falls, M.; Holtzapple, M.T. Oxidative Lime Pretreatment of Alamo Switchgrass. Appl. Biochem. Biotechnol. 2011, 165, 506-522. [CrossRef] [PubMed]

18. Park, J.-Y.; Shiroma, R.; Al-Haq, M.I.; Zhang, Y.; Ike, M.; Arai-Sanoh, Y.; Ida, A.; Kondo, M.; Tokuyasu, K. A novel lime pretreatment for subsequent bioethanol production from rice straw-Calcium capturing by carbonation $(\mathrm{CaCCO})$ process. Bioresour. Technol. 2010, 101, 6805-6811. [CrossRef]

19. Sun, C.; Xie, Y.; Hou, F.; Yu, Q.; Wang, Y.; Wang, X.; Miao, C.; Ma, J.; Ge, W.; Zhang, T.; et al. Enhancement on methane production and anaerobic digestion stability via co-digestion of microwave- $\mathrm{Ca}(\mathrm{OH})_{2}$ pretreated sugarcane rind slurry and kitchen waste. $J$. Clean. Prod. 2020, 264, 121731. [CrossRef]

20. Hu, Y.; Pang, Y.; Yuan, H.; Zou, D.; Liu, Y.; Zhu, B.; Chufo, W.A.; Jaffar, M.; Li, X. Promoting anaerobic biogasification of corn stover through biological pretreatment by liquid fraction of digestate (LFD). Bioresour. Technol. 2015, 175, 167-173. [CrossRef]

21. Guan, R.; Li, X.; Wachemo, A.C.; Yuan, H.; Liu, Y.; Zou, D.; Zuo, X.; Gu, J. Enhancing anaerobic digestion performance and degradation of lignocellulosic components of rice straw by combined biological and chemical pretreatment. Sci. Total Environ. 2018, 637-638, 9-17. [CrossRef]

22. Liu, T.; Zhou, X.; Li, Z.; Wang, X.; Sun, J. Effects of liquid digestate pretreatment on biogas production for anaerobic digestion of wheat straw. Bioresour. Technol. 2019, 280, 345-351. [CrossRef] [PubMed]

23. Sun, J.; Li, Z.; Zhou, X.; Wang, X.; Liu, T.; Cheng, S. Investigation on methane yield of wheat husk anaerobic digestion andits enhancement effect by liquid digestate pretreatment. Anaerobe 2019, 59, 92-99. [CrossRef]

24. Pang, Y.Z.; Liu, Y.P.; Li, X.J.; Wang, K.S.; Yuan, H.R. Improving Biodegradability and Biogas Production of Corn Stover through Sodium Hydroxide Solid State Pretreatment. Energy Fuels 2008, 22, 2761-2766. [CrossRef]

25. Holliger, C.; Alves, M.; Andrade, D.; Angelidaki, I.; Astals, S.; Baier, U.; Bougrier, C.; Buffière, P.; Carballa, M.; De Wilde, V.; et al. Towards a standardization of biomethane potential tests. Water Sci. Technol. 2016, 74, 2515-2522. [CrossRef]

26. Zhu, J.; Yang, L.; Li, Y. Comparison of premixing methods for solid-state anaerobic digestion of corn stover. Bioresour. Technol. 2015, 175, 430-435. [CrossRef] [PubMed]

27. Federation, W.E.; APH Association. Standard Methods for the Examination of Water and Wastewater; AWWA/WEF/APHA: Washington, DC, USA, 2005.

28. Sluiter, A.; Hames, B.; Ruiz, R.; Scarlata, C.; Sluiter, J.; Templeton, D.; Crocker, D. Determination of Structural Carbohydrates and Lignin in Biomass. Laboratory Analytical Procedure; National Renewable Energy Laboratory: Golden, CO, USA, 2010; TP-510-42618.

29. Lay, J.; Li, Y.; Noike, T.; Endo, J.; Ishimoto, S. Analysis of environmental factors affecting methane production from high solids organic waste. Water Sci. Technol. 1997, 36, 493-500. [CrossRef]

30. Li, Y.; Yang, G.; Li, L.; Sun, Y. Bioaugmentation for overloaded anaerobic digestion recovery with acid-tolerant methanogenic enrichment. Waste Manag. 2018, 79, 744-751. [CrossRef]

31. Alavi-Borazjani, S.A.; Capela, I.; Tarelho, L.A. Over-acidification control strategies for enhanced biogas production from anaerobic digestion: A review. Biomass-Bioenergy 2020, 143, 105833. [CrossRef]

32. Jönsson, L.J.; Martín, C. Pretreatment of lignocellulose: Formation of inhibitory by-products and strategies for minimizing their effects. Bioresour. Technol. 2016, 199, 103-112. [CrossRef]

33. Braz, G.H.R.; Fernandez-Gonzalez, N.; Lema, J.; Carballa, M. The time response of anaerobic digestion microbiome during an organic loading rate shock. Appl. Microbiol. Biotechnol. 2018, 102, 10285-10297. [CrossRef]

34. Reilly, M.; Dinsdale, R.; Guwy, A. Mesophilic biohydrogen production from calcium hydroxide treated wheat straw. Int. J. Hydrogen Energy 2014, 39, 16891-16901. [CrossRef]

35. Ajayi-Banji, A.A.; Rahman, S.; Cihacek, L.; Nahar, N. Comparison of the Reactor Performance of Alkaline-Pretreated Corn Stover Co-digested with Dairy Manure under Solid-State. Waste Biomass-Valorization 2020, 11, 5211-5222. [CrossRef]

36. Halil, S. Enhancement in methane yield from anaerobic co-digestion of walnut shells and cattle manure. Environ. Prog. Sustain. 2020, 39, e13524.

37. Mirmohamadsadeghi, S.; Karimi, K.; Azarbaijani, R.; Yeganeh, L.P.; Angelidaki, I.; Nizami, A.-S.; Bhat, R.; Dashora, K.; Vijay, V.K.; Aghbashlo, M.; et al. Pretreatment of lignocelluloses for enhanced biogas production: A review on influencing mechanisms and the importance of microbial diversity. Renew. Sustain. Energy Rev. 2021, 135, 110173. [CrossRef]

38. Meng, L.; Xie, L.; Kinh, C.T.; Suenaga, T.; Hori, T.; Riya, S.; Terada, A.; Hosomi, M. Influence of feedstock-to-inoculum ratio on performance and microbial community succession during solid-state thermophilic anaerobic co-digestion of pig urine and rice straw. Bioresour. Technol. 2018, 252, 127-133. [CrossRef]

39. Ma, X.; Jiang, T.; Chang, J.; Tang, Q.; Luo, T.; Cui, Z. Effect of Substrate to Inoculum Ratio on Biogas Production and Microbial Community during Hemi-Solid-State Batch Anaerobic Co-digestion of Rape Straw and Dairy Manure. Appl. Biochem. Biotechnol. 2019, 189, 884-902. [CrossRef] [PubMed] 